\title{
Effects of Bax Gene Deletion on Muscle and Motoneuron Degeneration in a Sexually Dimorphic Neuromuscular System
}

\author{
Dena A. Jacob, C. Lynn Bengston, and Nancy G. Forger \\ Department of Psychology and Center for Neuroendocrine Studies, University of Massachusetts, Amherst, Massachusetts 01003
}

\begin{abstract}
Motoneurons in the spinal nucleus of the bulbocavernosus (SNB) and their target muscles in the perineum, bulbocavernosus (BC), and levator ani (LA) normally degenerate in female rodents. Death of the motoneurons and muscles can be prevented by androgen treatments around the time of birth. To identify the intracellular mechanisms underlying hormone-dependent survival of this neuromuscular system, we examined mice with a targeted disruption of the pro-death gene Bax. SNB motoneuron number was increased in female Bax-/- mice, whether measured using immunolabeling for a motoneuron-specific marker or retrograde labeling with the fluorescent tracer Fluoro-Gold. Based on retrograde tracing, the sex difference in SNB cell number is eliminated in Bax-/- mice. Thus, Bax is required for sexually dimorphic motoneuron death in the SNB, and motoneurons rescued by Bax deletion project their axons to the periphery. Mean soma size in the SNB of $B a x-/-$ females is reduced, however, and there is a subpopulation of very small cells in the SNB of female knock-outs. In addition, the BC muscle was not identified in any female, regardless of Bax gene status. All females possessed a small LA muscle, and Bax deletion resulted in a tripling of LA fiber number in females. This increase was small, however, relative to the $>50$-fold sex difference in LA muscle fiber number. Thus, the sex difference in the perineal muscles is mostly unaffected by the absence of Bax protein, and SNB motoneuron number is dissociated from target muscle size in Bax-/- animals.
\end{abstract}

Key words: Bax; motoneuron; neuromuscular; androgen; spinal nucleus of the bulbocavernosus (SNB); sex difference; levator ani

\section{Introduction}

Naturally occurring cell death is a nearly ubiquitous feature of the developing nervous system and is thought to numerically match afferent neurons with their target cells (Oppenheim, 1991). This phenomenon has been best studied for spinal motoneurons, in which size of the target musculature controls the magnitude of cell death (Hollyday and Hamburger, 1976; Grieshammer et al., 1998). The spinal nucleus of the bulbocavernosus (SNB) of rodents presents a unique example of sexually dimorphic, targetdependent motoneuron death and the opportunity to examine mechanisms controlling the regulation of both muscle and motoneuron survival.

SNB motoneurons reside in the lower lumbar spinal cord and innervate the striated perineal muscles bulbocavernosus (BC), levator ani (LA), and external anal sphincter (Schroder, 1980). Both sexes possess BC/LA muscles and similar numbers of SNB cells prenatally. The postnatal persistence of this system is dependent on androgens, however, and the motoneurons and muscles degenerate in females around the time of birth (Cihak et al., 1970; Nordeen et al., 1985). Treating females with testosterone during

Received March 28, 2005; revised May 5, 2005; accepted May 5, 2005

This work was supported by National Institutes of Health Grants HD33044, MH068482, and MH072825. We thank Geert de Vries for helpful comments on a previous version of this paper.

Correspondence should be addressed to Dena A. Jacob, Department of Psychology and Center for Neuroendocrine Studies, University of Massachusetts, Amherst, MA 01003. E-mail: denaj@nsm.umass.edu.

DOI:10.1523/JNEUROSCI.1200-05.2005

Copyright $\odot 2005$ Society for Neuroscience $\quad$ 0270-6474/05/255638-07\$15.00/0 the perinatal period permanently rescues SNB cells and masculinizes BC/LA muscle morphology (Breedlove and Arnold, 1983; Nordeen et al., 1985; Wagner and Clemens, 1989). Several lines of evidence suggest that androgens act at the perineal muscles (Freeman et al., 1996) and that trophic factors from the muscles secondarily promote the survival of SNB motoneurons (Forger et al., 1993, 1997; Xu et al., 2001).

The human homolog of the SNB is also sexually dimorphic (Forger and Breedlove, 1986) and exhibits unusual susceptibility to disease. Perineal motoneurons are relatively spared in both the human form of amyotrophic lateral sclerosis and a mouse model of the disease but are more vulnerable than other spinal motoneurons to Shy-Drager syndrome (Mannen et al., 1982; Hamson et al., 2002). Thus, in addition to furthering our understanding of neural sex differences, the mechanisms controlling the survival of perineal motoneurons are of clinical interest.

Cell death in many tissues is crucially controlled by members of the Bcl-2 family of proteins, some of which prevent (e.g., Bcl-2, $\mathrm{Bcl}_{\mathrm{XL}}$ ), and others that promote (e.g., Bax, Bak) apoptosis (Merry and Korsmeyer, 1997; Adams and Cory, 2001). We have reported previously that overexpression of $\mathrm{Bcl}-2$ partially masculinizes the number of SNB cells in female mice (Zup et al., 2003). However, the effects of $\mathrm{Bcl}-2$ overexpression were modest, and an overexpression study does not address the physiological relevance of a given protein. Here, we used mice with a targeted disruption of the Bax gene to determine whether Bax is required for the sexually dimorphic cell death of motoneurons in the SNB. If so, then 
the sex difference in motoneuron number might be eliminated in Bax-/- animals. Bax deletion increases the number of nonsexually dimorphic motoneurons, without affecting their target muscles (Deckwerth et al., 1996; Sun et al., 2003). The BC/LA muscles are exceptional, however, in that they normally degenerate in one sex. We therefore took advantage of the androgen dependence of the BC/LA muscles to assess the requirement for Bax in naturally occurring, striated muscle cell death.

\section{Materials and Methods}

Animals. Mice heterozygous for the Bax gene deletion on a C57BL/6 background were obtained from the The Jackson Laboratory (Bar Harbor, ME). These animals were derived from the original Bax knock-out described by Knudson et al. (1995). Bax $+/+$ and Bax - /- offspring were generated by mating heterozygous animals and were genotyped by PCR amplification of tail DNA. A set of three primers (Bax exon 5 forward primer, Bax intron 5 reverse primer, and Neo reverse primer) were used as by White et al. (1998). All animals were killed as adults (60-120 d of age) by overdose with chlorapent and perfused as described below.

Immunocytochemistry for the motoneuron marker SMI-32. Because neurons rescued by Bax deletion may be atrophic and not innervate normal target sites (Deckwerth et al., 1996; Bar-Peled et al., 1999; Sun et al., 2003), we assessed SNB cell number using both immunolabeling for a motoneuron-specific marker and retrograde labeling after peripheral injections of a fluorescent tracer. SMI-32 is a mouse monoclonal antibody (Sternberger Monoclonals, Lutherville, MD) that binds to nonphosphorylated epitopes in neurofilament $\mathrm{H}$ and specifically labels motoneurons within the spinal cord (Bar-Peled et al., 1999). Animals were perfused intracardially with saline followed by $10 \%$ buffered formalin. Lumbosacral spinal cords were removed, postfixed in formalin, and immersed in Bouin's solution for $3 \mathrm{~d}$ before paraffin embedding. Cords were sectioned in the coronal plane at $12 \mu \mathrm{m}$ and mounted onto slides. Immunocytochemistry was performed following the recommendations of the manufacturer. Briefly, tissue sections were deparaffinized and rinsed three times with $0.05 \mathrm{M}$ Tris, $\mathrm{pH} 7.6 / 1.5 \%$ sodium chloride (1.5 T). Slides were then submersed in deionized water and autoclaved at $121^{\circ} \mathrm{C}$ for 5 min. Sections were incubated with $3 \%$ normal goat serum for $30 \mathrm{~min}$ and with the primary antibody at a 1:1000 concentration overnight. Sections were then exposed to a 1:150 concentration of goat anti-mouse secondary antibody for $30 \mathrm{~min}$ followed by a 1:200 concentration of ClonoPAP (a peroxidase-mouse antiperoxidase complex; Sternberger Monoclonals) for $30 \mathrm{~min}$. Slides were rinsed three times in $1.5 \mathrm{~T}$ before each incubation, and all incubations took place in a humidified chamber. Nickel-enhanced diaminobenzidine was used for color reaction.

Fluoro-Gold labeling. Adult Bax $+/+$ and Bax $-/-$ mice of both sexes were anesthetized with a ketamine mixture $(100 \mathrm{mg} / \mathrm{kg}$ ketamine, 10 $\mathrm{mg} / \mathrm{kg}$ xylazine; $0.1 \mathrm{ml} / 10 \mathrm{~g}$ body weight), and Fluoro-Gold (FG; $4 \%$ aqueous solution; Fluorochrome, Denver, CO) was injected subcutaneously into the perineum, midway between the anus and phallus. Our goal was to flood the perineum and thereby label most or all SNB motoneurons. Because the perineal space is much larger in males than in females, we experimented with two different injection volumes: 10 and $40 \mu$ l. The larger injections tended to label more SNB cells in both sexes but resulted in leakage from the injection site and swollen, red perineums in females. In preliminary data analyses, we used separate two-way ANOVAs to compare SNB motoneuron number after $10 \mu \mathrm{l}$ injections or when data from both injection volumes were combined (the number of females receiving $40 \mu \mathrm{l}$ injections was too small to allow for a separate analysis of those data). The pattern of statistical significance was identical for main effects and interactions. Planned comparisons also showed the same pattern of results for both analyses, with the exception that the number of labeled SNB motoneurons was higher in Bax $-/-$ than in Bax $+/+$ males when data from the two injection volumes were combined, but the male groups did not differ significantly after $10 \mu \mathrm{l}$ injections. Data from the combined analysis are given below.

To compare motoneuron labeling from perineal flooding with direct intramuscular injections, FG was injected into the BC/LA complex of an additional cohort of Bax-/- males. A midline incision was made in the skin between the anus and penis, the muscle was visualized, and three 1 $\mu \mathrm{l}$ injections of FG were made into each side (total of $6 \mu \mathrm{l}$ ). Note that it is not possible to directly inject the BC/LA of females because of their extremely small size (see below). A $1 \mu$ injection of FG was also administered into the plantar surface of each foot, targeting the flexor digitorum brevis. This intrinsic foot muscle is the primary target of retrodorsolateral nucleus (RDLN) motoneurons (Nicolopoulos-Stournaras and Iles, 1983), which reside in the lateral horn at the same level of the spinal cord as the SNB. The RDLN is not sexually dimorphic, and RDLN cell number is not affected by perinatal hormone manipulations (Jordan et al., 1982).

After a $5 \mathrm{~d}$ survival, animals were perfused with $0.9 \%$ saline followed by $4 \%$ paraformaldehyde. Lumbosacral spinal cords were removed, postfixed in formalin for $2 \mathrm{~d}$, and immersed in $20 \%$ sucrose overnight. Cords were sectioned in the coronal plane at $40 \mu \mathrm{m}$ on a freezing microtome. Alternate sections were mounted onto slides, dehydrated, and coverslipped with DePeX mounting medium for counts of fluorescently labeled cells.

Motoneuron number and size. SMI-32-positive and FG-labeled SNB motoneurons were counted bilaterally in alternate sections. For comparison, motoneuron number in the RDLN was also counted in the same tissue. Only those motoneurons in which the nucleus was visible were included in the SMI-32 counts, whereas all fluorescing cell bodies were counted in FG-labeled tissue. For cell-size analysis, $\sim 30$ SNB motoneurons were traced from each animal and cross-sectional area determined using Sigma Scan 3.0 (Jandel Scientific, San Rafael, CA) software. All sections chosen for cell-size analysis were spaced equally throughout the rostrocaudal extent of the nucleus, and every SNB motoneuron was traced from each selected section to avoid experimenter bias. Only the somata of FG-labeled cells could be clearly discerned, whereas both somata and nuclei were evaluated in SMI-32-labeled sections. A preliminary three-way ANOVA (sex-by-genotype-by-injection volume) revealed no effect of FG injection volume on soma size $(p>0.20)$; therefore, cell-size data from animals injected with 10 and $40 \mu \mathrm{l} \mathrm{FG}$ were pooled in the analyses reported below.

BC/LA muscle mass and muscle fiber counts. The BC/LA muscles from males in the SMI-32 experiment were dissected out after perfusion, trimmed of fat, and weighed. BC/LA muscles were not visible in Bax-/or $\mathrm{Bax}+/+$ females, based on gross dissection. To more closely examine muscle development, a block of tissue containing the perineum was dissected out from females and males after perfusion, placed in Bouin's solution for 1 week, embedded in paraffin, and cut in cross section with respect to the rectum at a thickness of $10 \mu \mathrm{m}$. The LA angles anteriorly as it loops around the sides of the rectum, and its tiny size in females allows for the entire muscle to be captured in cross section in a single view. A similar analysis was not possible for the much larger LA muscles of males. Instead, the BC/LA complex was dissected out of an additional cohort of $\mathrm{Bax}-/-$ and $\mathrm{Bax}+/+$ mice that were killed by $\mathrm{CO}_{2}$ inhalation. Muscles were rapidly frozen in dry ice-cooled isopentane and cross sectioned at 10 $\mu \mathrm{m}$ on a cryostat. Sections were stained with Gomori's trichrome, and LA fibers were counted bilaterally from sections in which muscle girth was maximal and fibers appeared in near-perfect cross section. The mean of left and right LA fiber counts were then determined for each animal.

Data analysis. Motoneuron number and size were analyzed by twoway ANOVAs (sex-by-genotype), followed by planned comparisons using Fisher's least significant difference. $\chi^{2}$ analysis was used to compare the distribution of SNB cell size in wild-type and Bax knock-out females, and $t$ tests were used to compare muscle fiber counts within each sex of Bax $+/+$ and Bax $-/-$ animals. Means are reported \pm SEMs, and $p<$ 0.05 was considered statistically significant.

\section{Results}

\section{SMI-32-labeled cell counts}

SMI-32 labeling was limited to large, multipolar cells in the SNB, RDLN, and dorsolateral nucleus and appeared motoneuron specific (Fig. 1A), as described previously (Bar-Peled et al., 1999). Based on the criterion of SMI-32 labeling, Bax gene deletion reduced but did not eliminate the sex difference in SNB cell number 

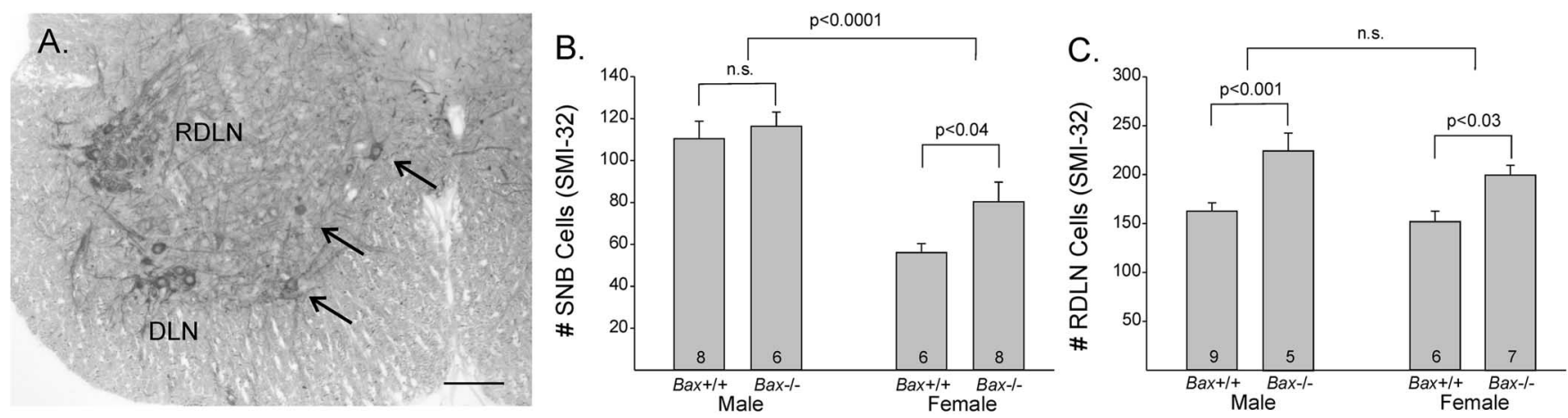

Figure 1. A, Photomicrograph of SMI-32-labeled cells in the lower lumbar spinal cord. Arrows point to SNB neurons. DLN, Dorsolateral nucleus. Scale bar, $100 \mu \mathrm{m} . \boldsymbol{B}, C$, Mean number of cells positive for SMI-32 in the SNB and RDLN of Bax +/+ and Bax - / - mice. The number of animals per group is indicated at the base of each bar. n.s., Not significant. Error bars represent SEM.

(Fig. $1 B$ ). ANOVA confirmed the expected main effect of sex, with more cells in males than in females $(p<0.0005)$. There was a marginal main effect of genotype $(p=0.07)$ and no sex-bygenotype interaction $(p>0.25)$. SNB cell counts of Bax-/females were $\sim 40 \%$ higher than in wild-type females, and a planned comparison indicates that this difference was significant $(p<0.05)$ (Fig. $1 B)$. However, Bax $-/-$ males still had significantly more SMI-32-positive SNB motoneurons than did Bax-/- females $(p<0.0005)$.

In the nonsexually dimorphic RDLN, we find a main effect of genotype $(p<0.0005)$, with Bax deletion increasing motoneuron number by $\sim 35 \%$ (Fig. $1 C$ ). The increase was significant for both males $(p<0.002)$ and females $(p<0.01)$. As expected, there was no effect of sex and no sex-by-genotype interaction on cell number in the RDLN (Fig. 1C).

\section{Retrograde labeling of motoneurons}

Previous investigators have noted that motoneurons rescued by Bax gene deletion may be atrophic and not meet the normal criteria for inclusion in motoneuron counts based on appearance in a Nissl stain or immunoreactivity for a motoneuron-specific marker (Sun et al., 2003). Retrograde labeling with FG allowed us to identify SNB motoneurons without regard to cell size or staining characteristics and to address the question of whether rescued cells project to the periphery. In pilot work, we confirmed that injections of FG into the perineal space resulted in motoneuron labeling confined to the SNB and the dorsolateral nucleus, a cell group that also innervates perineal muscles, and can readily be distinguished from the SNB based on position in the cord. The position and morphology of labeled cells within the SNB after flooding the perineum with FG was indistinguishable from that seen after direct injection of the BC/LA muscles of males (Fig. 2A) (supplemental Fig. 1, available at www.jneurosci.org as supplemental material). RDLN motoneurons located in the same section of the spinal cord were labeled only after injections into the plantar surface of the foot (Fig. 2A).

Counts of retrogradely labeled cells indicate that Bax gene deletion eliminates the sex difference in SNB motoneuron number. As expected, FG labeled more SNB motoneurons in Bax $+/+$ males than in Bax $+/+$ females $(p=0.005)$ (Fig. $2 B)$. SNB motoneuron number was increased in Bax-null mice, and this was significant for both males $(p<0.005)$ and females $(p<0.0005)$. However, the increase was greater for females $(100 \%)$ than for males $(21 \%)$, and, as a result, the sex difference in SNB motoneuron number was eliminated in Bax-/- animals. In fact, Bax-/females had slightly (nonsignificantly) more SNB motoneurons than did Bax $-/-$ males. Statistically, these results were reflected in a main effect of genotype $(p<0.0005)$, no main effect of sex $(p>0.2)$, and a significant sex-by-genotype interaction $(p<$ $0.005)$. The number of labeled SNB cells in Bax-/- females also was equivalent to that in $B a x-/-$ males receiving direct injections of FG into the BC/LA muscle $(p>0.25)$ (Fig. $2 B$, dashed line). Thus, both injection methods indicate that $\mathrm{Bax}-/-\mathrm{fe}-$ males have as many SNB motoneurons as do Bax-/- males.

Counts of RDLN motoneurons based on retrograde labeling with FG again revealed a main effect of genotype $(p<0.001)$, with Bax deletion increasing cell number by $53 \%$. This increase was significant for males $(p<0.005)$ and marginally significant for females ( $p=0.052$ ) (Fig. $2 C$ ). There was no effect of sex and no sex-by-genotype interaction on the number of RDLN motoneurons labeled by injections of FG into target muscles of the foot.

\section{SNB motoneuron cell size}

Cell size analysis provided a possible explanation for the difference in outcome between the SMI-32 and FG cell counts (supplemental Table 1, available at www.jneurosci.org as supplemental material). In SMI-32-labeled material, we found the expected main effect of sex, with larger cells in males $(p<0.001)$, but no effect of genotype and no sex-by-genotype interaction for either soma or nucleus size. FG-labeled cell size exhibited a main effect of sex (male $>$ female; $p<0.0001$ ) but also a significant main effect of genotype $(p<0.01)$ and a sex-by-genotype interaction $(p=0.015)$. The latter resulted from the fact that SNB cell size was reduced by Bax deletion in females $(p<0.001)$ but not in males $(p=0.80)$ (supplemental Table 1 , available at www. jneurosci.org as supplemental material). A frequency distribution of the size of FG-labeled cells reveals a peak of very small motoneurons $\left(100-200 \mu \mathrm{m}^{2}\right)$ in Bax-/- females that is not seen in Bax $+/+$ females (supplemental Fig. 2, available at www. jneurosci.org as supplemental material). The position of these small cells did not differ from that of larger SNB motoneurons (supplemental Fig. 1, available at www.jneurosci.org as supplemental material). Together, these findings suggest that FG labels a pool of very small SNB motoneurons in Bax $-/-$ females that is not SMI-32 immunoreactive.

\section{Target muscle size}

Gross examination revealed well developed BC/LA muscles in $B a x+/+$ and Bax $-/-$ males, with no difference in wet weight between the groups $(147 \pm 4$ vs $146 \pm 5 \mathrm{mg}$ for Bax $+/+$ and Bax $-/-$, respectively; $p>0.8$ ). No LA or BC muscles could be seen in any female on gross dissection. Microscopically, however, we observed a very small LA muscle wrapping around the rectum 


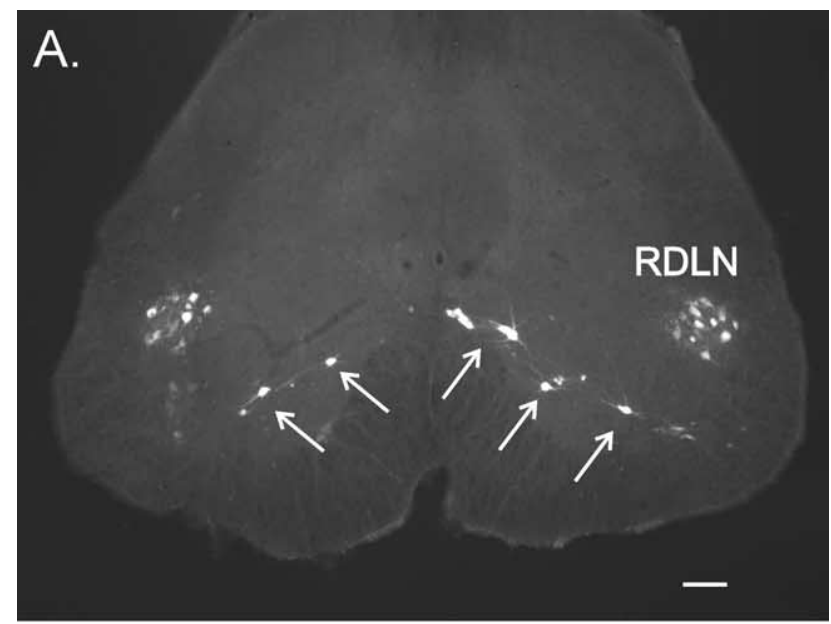

B.

n.s.

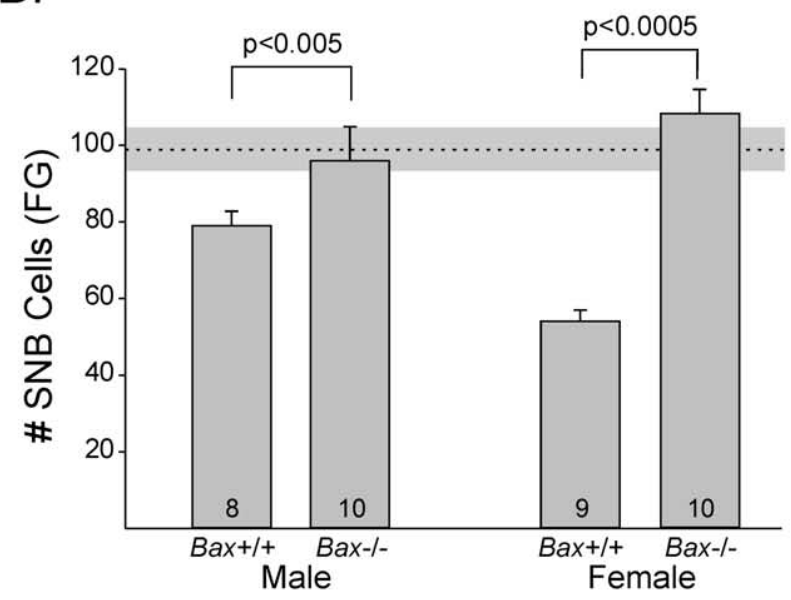

C.

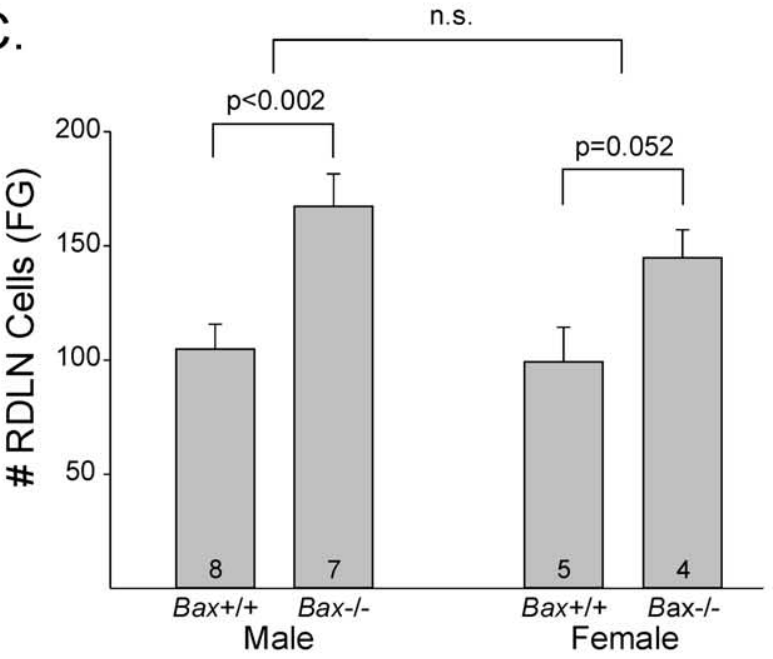

Figure 2. $\boldsymbol{A}$, Motoneurons in the SNB and RDLN retrogradely labeled after FG injections into the perineum and plantar surface of the foot of a Bax-/- female. Scale bar, $100 \mu \mathrm{m} . \boldsymbol{B}, \boldsymbol{C}$, Mean counts of FG-labeled motoneurons in the SNB and RDLN of Bax $+/+$ and Bax $-/-$ animals. Bax deletion increased motoneuron number and eliminated the sex difference in the SNB. The number of animals per group is indicated at the base of each bar. The dotted horizontal line in $\boldsymbol{B}$ indicates the mean \pm SEM (shading) number of SNB motoneurons labeled by direct injection of FG into the $\mathrm{BC} / \mathrm{LA}$ muscles of $\mathrm{Bax}-/-$ males $(n=7)$. n.S., Not significant. Error bars represent SEM.
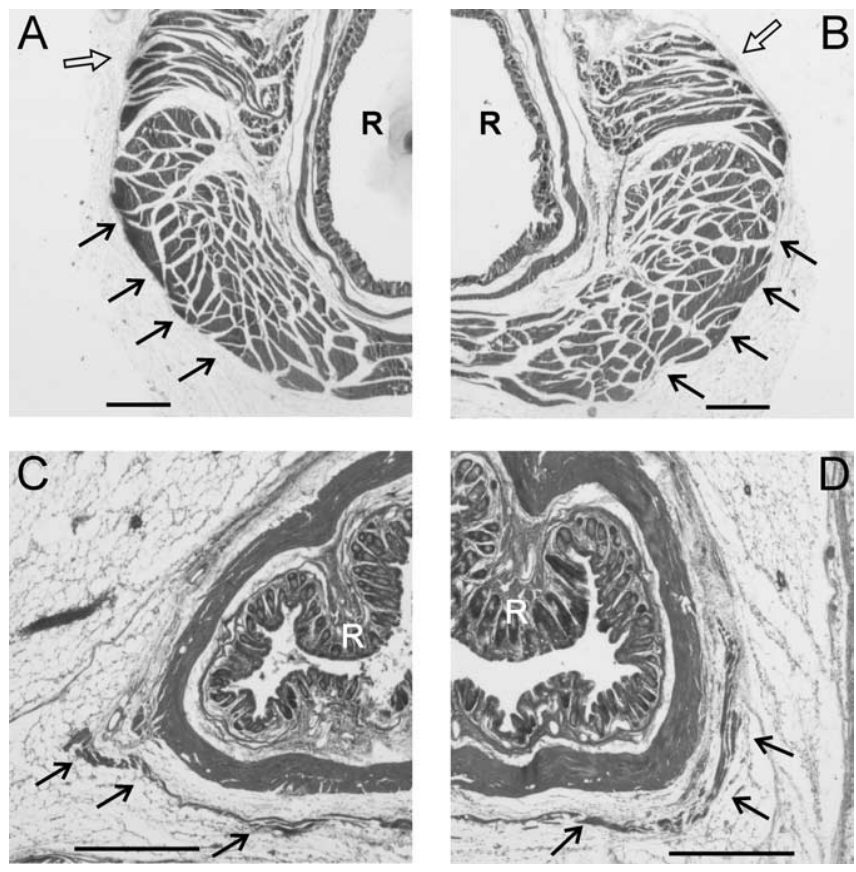

Figure 3. Low-power photomicrographs of sections through the perineums of a $\mathrm{Bax}+/+$ male $(\boldsymbol{A})$, Bax $-/-$ male $(\boldsymbol{B}), B a x+/+$ female $(\boldsymbol{C})$, and Bax $-/-$ female $(\boldsymbol{D})$. Filled arrows indicate the LA muscle, which is severely reduced in size in females, regardless of Bax genotype. Note that female sections are shown at a higher magnification than those of males. Scale bar, $500 \mu \mathrm{m}$. Open arrows indicate a portion of the $\mathrm{BC}$ muscle in males. $\mathrm{R}$, Rectum.

in females (Fig. 3). The BC was not definitively identified in any female, although we did find small clusters of striated muscle fibers surrounding the urethra and vagina of both Bax $+/+$ and Bax-/- females that may be remnants of the BC. LA fiber number ranged from 34 to 155 in females and was significantly higher in Bax $-/-$ than in Bax $+/+$ animals $(p<0.0005)$ (Figs. 3, 4). However, this contrasts with LA fiber counts in males, in which both genotypes had $>2000$ large muscle fibers, which were tightly packed into fascicles separated by connective tissue (Figs. 3, 4). Thus, even in the Bax-/- females, LA fiber number was only $\sim 5 \%$ of that seen in males, indicating that the gross sex difference in muscle size is not eliminated by Bax gene status.

\section{Discussion}

Bax deletion increased SNB motoneuron number in females, whether measured immunocytochemically or by retrograde labeling. Thus, this pro-death member of the Bcl-2 family is essential for the normal sex difference in SNB cell number. A knockout of the Bax gene markedly reduces the number of apoptotic cells in lateral horn motor nuclei during development (White et al., 1998), and, in all likelihood, Bax deletion eliminated the sex difference in the SNB by rescuing cells that would otherwise die during perinatal life. In contrast, Bax gene status had little effect on the gross sex difference in size of the BC/LA muscles. Thus, sexual differentiation of the perineal muscles is, for the most part, not Bax dependent, and SNB motoneuron survival is dissociated from target muscle survival in Bax-/- animals.

Although increases in SNB motoneuron number were detected in Bax-/- females by both SMI-32 immunocytochemistry and retrograde tracing, the magnitude of the effects differed. Bax deletion increased SNB cell number $\sim 40 \%$ in females based on SMI-32 staining and 100\% in FG-labeled material. We propose that some SNB motoneurons rescued by Bax deletion are 

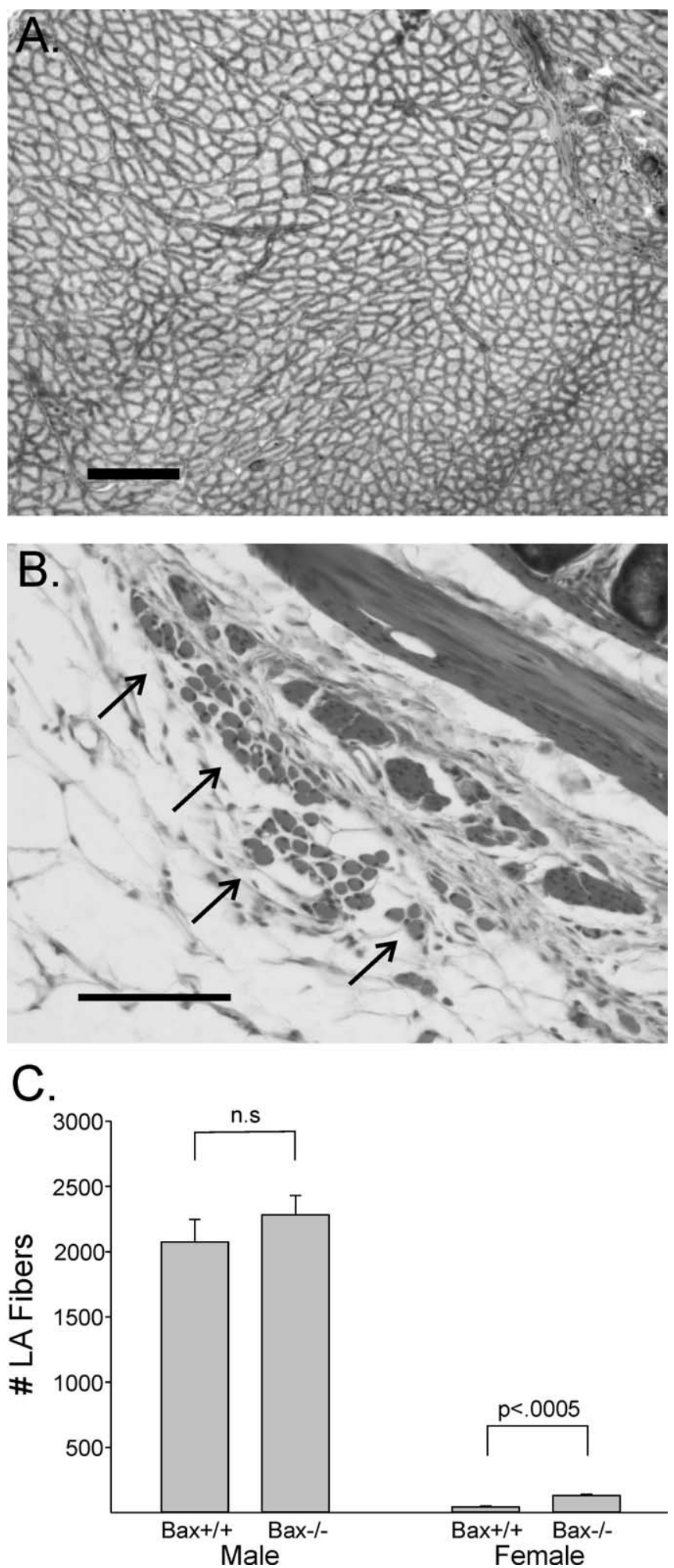

Figure 4. High-power photomicrographs of trichrome-stained sections through the LA muscle of a Bax-/- male $(\boldsymbol{A})$ and female $(\boldsymbol{B})$. LA muscles of males were dissected out and frozen sectioned; the view shown includes $\sim 65 \%$ of the total muscle fibers. The muscles of females were too small for dissection and were analyzed in situ in paraffin-embedded sections through the perineum. Arrows in $\boldsymbol{B}$ indicate LA fibers just outside of the smooth muscle (diagonal band at top right) and connective tissue associated with the rectum. Scale bars: $A, 200 \mu \mathrm{m}$; B, $100 \mu \mathrm{m}$. C, Mean counts of LA fibers in Bax $+/+$ and Bax $-/-$ mice. $n=2$ Bax $+/+$ males, $n=3 B a x-/-$ males, $n=4 B a x+/+$ females, and $n=4 B a x-/-$ females. $n$.s., Not significant. Error bars represent SEM. missed in counts that depend on factors such as cell size or the expression of specific markers. Retrograde labeling with FG identifies a subpopulation of very small SNB motoneurons in females. These cells might be omitted in SMI-32 counts if the expression of neurofilament $\mathrm{H}$ (the antigen recognized by SMI-32) is reduced or absent. This explanation could also underlie the relatively small effect of Bcl-2 overexpression on SNB motoneuron number in a previous study (Zup et al., 2003) in which counts relied exclusively on appearance of Nissl-stained cells. Similarly, Sun and colleagues observed a subset of motoneurons in the lateral horn of Bax-/- animals that were atrophic and did not meet the criteria for inclusion in motoneuron counts based on Nissl or SMI-32 staining. Ultrastructural analysis revealed that these cells contained a marked reduction in cytoplasm but otherwise appeared healthy and displayed a regenerative response to growth factors (Sun and Oppenheim, 2003; Sun et al., 2003). Presumably, motoneurons that are unsuccessful in the competition for target-derived trophic support do not die in Bax-/mice but undergo cell atrophy.

Our results differ from those of previous investigators in that we were able to retrogradely label the supernumerary motoneurons in Bax $-/-$ mice. In contrast, injections of the tracer DiI into limb muscles of postnatal Bax-/- mice did not label more motoneurons than in wild-type controls, suggesting that motoneurons rescued by Bax deletion do not project beyond the proximal ventral root (Sun et al., 2003). The tracers used in the two studies (DiI vs FG) or the method of tracer delivery may account for the different outcomes. To label SNB motoneurons, we flooded the perineal space with fairly large volume injections of FG; such an application could reach axons that terminate at some distance from the target muscles. However, this explanation cannot account for the fact that we also saw more motoneurons in the RDLN of Bax-/- mice, based on small, localized injections of FG into the foot. We conclude that at least some motoneurons rescued by Bax deletion project their axons to the area of their target muscles. Whether they actually form functional synaptic contacts with the targets remains an open question.

In contrast to the well established literature on apoptosis in developing neurons, relatively little is known about the control of striated muscle cell death. The wet weight and fiber number of limb muscles is normal in Bax knock-out animals (Sun et al., 2003; Nowak et al., 2004), but the muscles examined do not normally degenerate. The BC muscle completely degenerates in female rats around the time of birth, whereas a remnant LA persists in at least some females (Cihak et al., 1970; Tobin and Joubert, 1988). Most SNB motoneurons that survive the perinatal cell death period in female rats innervate the vestigial LA or the nondimorphic external anal sphincter (McKenna and Nadelhaft, 1986; Tobin and Joubert, 1988). Although the SNB neuromuscular system has been best studied in rats, the androgen dependence and developmental profile of the perineal muscles appears similar in mice (Wagner and Clemens, 1989; Forger et al., 1993; Park et al., 1999). Perineal muscle morphology is also altered by androgen manipulations during development in dogs, spotted hyenas, and gerbils (Forger and Breedlove, 1986; Forger et al., 1996; Siegford et al., 2003).

We find that LA muscle fiber number is approximately threefold higher in Bax-/- females than in controls, uncovering a potentially interesting and unprecedented effect of Bax deletion on muscle development. However, this increase is minor in contrast to the nearly 50 -fold sex difference in LA fiber number. A coherent BC muscle was not identified in any female, although we did find a few small clusters of muscle fibers that could be vestiges 
of the female BC. We did not attempt counts of putative BC remnants; however, simple observation suggests no difference based on Bax gene status and a sex difference in overall BC muscle size that is, if anything, more marked than for the LA.

Although it has long been known that size of the perineal muscles is extremely androgen sensitive, the sex differences in LA fiber number seen here are not likely to be caused by differences in adult levels of circulating hormones. Testosterone manipulations of adult male and female rats alter LA muscle fiber size, with no changes in fiber number (Wainman and Shipounoff, 1941; Venable, 1966; Joubert and Tobin, 1989). In addition, long-term testosterone treatment does not result in male-like BC/LA muscles in $\mathrm{Bax}+/+$ or Bax-/- females (our unpublished observations). Thus, the effect of Bax deletion on LA fiber number notwithstanding, most perineal muscle fibers die in females despite the absence of Bax. Similarly, the deletion of Bax elevates muscle fiber number slightly in a mouse model of human congenital muscular dystrophy, but not to the level seen in healthy controls (Girgenrath et al., 2004).

Bax is redundant with the Bcl-2 family protein Bak in many tissues, and in such cases, the genes for both Bax and Bak must be deleted to significantly inhibit cell death (Lindsten et al., 2000; Wei et al., 2001). Postmitotic neurons do not express full-length Bak protein (Sun et al., 2001; Uo et al., 2004), which likely accounts for the singular importance of Bax in the control of developmental neuronal cell death. In contrast, both Bak and Bax are expressed in developing mouse skeletal muscle (Dominov et al., 2001). Thus, we propose that Bax deletion had only minor effects on the perineal muscles, because Bax is redundant with Bak in this tissue. In this regard, it would be quite interesting to examine the BC/LA in Bax/Bak double knock-outs; according to our prediction, female double knock-outs might display fully masculine $\mathrm{BC} / \mathrm{LA}$ fiber number, despite the relative absence of androgens during perinatal life. It is also possible, however, that BC/LA muscle death occurs by a mechanism that is independent of Bcl-2 family proteins.

It is not known whether the effects of Bax deletion seen here are cell autonomous. It is possible that the increase in LA muscle fiber number of Bax-/- females is indirect and caused by anterograde effects of the increased number of innervating SNB motoneurons. The converse, that Bax deletion affected SNB motoneuron number only indirectly, as the result of Bax action at the muscle, seems less likely. Even if all SNB motoneurons in Bax-/- females innervate the LA, a comparison of muscle fiber and motoneuron number suggests that average motor unit size (i.e., number of LA fibers innervated by one SNB cell) would be reduced by $>90 \%$ in $B a x-/-$ females compared with that in males. In culture, motoneurons from Bax-null mice survive in the absence of added trophic factors (Bar-Peled et al., 1999), and lateral horn motoneuron number is elevated in Bax-/- mice with no change in muscle size and, in some cases, without target innervation by the rescued cells (Sun et al., 2003). Thus, effects of Bax deletion on motoneuron survival may be cell autonomous.

We recently reported that Bax deletion eliminates sex differences in neuron number in the bed nucleus of the stria terminalis and anteroventral periventricular nucleus of the mouse forebrain (Forger et al., 2004). Thus, hormone-regulated cell death converges on a common, Bax-dependent mechanism in at least three neural regions. The molecular cascades leading to Baxdependent cell death in these regions likely differ, however. SNB cell survival is androgen dependent (Breedlove and Arnold, 1981), whereas estrogenic metabolites of testosterone appear to control cell survival in the two forebrain regions (Arai et al., 1996;
Simerly et al., 1997). Moreover, gonadal steroid hormones increase cell death in the anteroventral periventricular nucleus while decreasing death in the bed nucleus of the stria terminalis and SNB. Thus, differences upstream of Bax related to the differences in receptor signaling and the valence of the hormone effect are likely. Identifying these differences, for example, by comparing the effects of testosterone on the expression of Bax and proteins that interact with Bax, is an important next step.

\section{References}

Adams JM, Cory S (2001) Life-or-death decisions by the Bcl-2 protein family. Trends Biochem Sci 26:61-66.

Arai Y, Sekine Y, Murakami S (1996) Estrogen and apoptosis in the developing sexually dimorphic preoptic area in female rats. Neurosci Res 25:403-407.

Bar-Peled O, Knudson M, Korsmeyer SJ, Rothstein JD (1999) Motor neuron degeneration is attenuated in bax-deficient neurons in vitro. J Neurosci Res 55:542-556.

Breedlove SM, Arnold AP (1981) Sexually dimorphic motor nucleus in the rat lumbar spinal cord: response to adult hormone manipulation, absence in androgen-insensitive rats. Brain Res 225:297-307.

Breedlove SM, Arnold AP (1983) Hormonal control of a developing neuromuscular system. I. Complete demasculinization of the male rat spinal nucleus of the bulbocavernosus using the anti-androgen flutamide. J Neurosci 3:417-423.

Cihak R, Gutmann E, Hanzlikova V (1970) Involution and hormoneinduced persistence of the M. sphincter (levator) ani in female rats. J Anat 106:93-110.

Deckwerth TL, Elliott JL, Knudson CM, Johnson Jr EM, Snider WD, Korsmeyer SJ (1996) BAX is required for neuronal death after trophic factor deprivation and during development. Neuron 17:401-411.

Dominov JA, Houlihan-Kawamoto A, Swap CJ, Miller JB (2001) Pro- and anti-apoptotic members of the Bcl-2 family in skeletal muscle: a distinct role for Bcl-2 in later stages of myogenesis. Dev Dyn 220:18-26.

Forger NG, Breedlove SM (1986) Sexual dimorphism in human and canine spinal cord: role of early androgen. Proc Natl Acad Sci USA 83:7527-7531.

Forger NG, Roberts SL, Wong V, Breedlove SM (1993) Ciliary neurotrophic factor maintains motoneurons and their target muscles in developing rats. J Neurosci 13:4720-4726.

Forger NG, Frank LG, Breedlove SM, Glickman SE (1996) Sexual dimorphism of perineal muscles and motoneurons in spotted hyenas. J Comp Neurol 375:333-343.

Forger NG, Howell ML, Bengston L, MacKenzie L, DeChiara TM, Yancopoulos GD (1997) Sexual dimorphism in the spinal cord is absent in mice lacking the ciliary neurotrophic factor receptor. J Neurosci 15:9605-9612.

Forger NG, Rosen GJ, Waters EM, Jacob D, Simerly RB, De Vries GJ (2004) Deletion of Bax eliminates sex differences in the mouse forebrain. Proc Natl Acad Sci USA 101:13666-13671.

Freeman LM, Watson NV, Breedlove SM (1996) Androgen spares androgen-insensitive motoneurons from apoptosis in the spinal nucleus of the bulbocavernosus in rats. Horm Behav 30:424-433.

Girgenrath M, Dominov JA, Kostek CA, Miller JB (2004) Inhibition of apoptosis improves outcome in a model of congenital muscular dystrophy. J Clin Invest 114:1635-1639.

Grieshammer U, Lewandoski M, Prevette D, Oppenheim RW, Martin GR (1998) Muscle-specific cell ablation conditional upon Cre-mediated DNA recombination in transgenic mice leads to massive spinal and cranial motoneuron loss. Dev Biol 197:234-247.

Hamson DK, Hu JH, Krieger C, Watson NV (2002) Lumbar motoneuron fate in a mouse model of amyotrophic lateral sclerosis. NeuroReport 13:2291-2294.

Hollyday M, Hamburger V (1976) Reduction of the naturally occurring motoneuron loss by enlargement of the periphery. J Comp Neurol 170:311-320.

Jordan CL, Breedlove SM, Arnold AP (1982) Sexual dimorphism and the influence of neonatal androgen in the dorsolateral motor nucleus of the rat lumbar spinal cord. Brain Res 249:309-314.

Joubert Y, Tobin C (1989) Satellite cell proliferation and increase in the number of myonuclei induced by testosterone in the levator ani muscle of the adult female rat. Dev Biol 131:550-557.

Knudson CM, Tung KS, Tourtellotte WG, Brown GA, Korsmeyer SJ (1995) 
Bax-deficient mice with lymphoid hyperplasia and male germ cell death. Science 270:96-99.

Lindsten T, Ross AJ, King A, Zong W-X, Rathmell JC, Shiels HA, Ulrich E, Waymire KG, Mhar P, Frauwirth K, Chen Y, Wei M, Eng VM, Adelman DM, Simon MC, Ma A, Golden JA, Evan G, Korsmeyer SJ, MacGregor GR, et al. (2000) The combined functions of proapoptotic Bcl-2 family members Bak and Bax are essential for normal development of multiple tissues. Mol Cell 6:1389-1399.

Mannen T, Iwata M, Toyokura Y, Nagashima K (1982) The Onuf's nucleus and the external anal sphincter muscles in amyotrophic lateral sclerosis and Shy-Drager's syndrome. Acta Neuropathol 58:255-260.

McKenna KE, Nadelhaft I (1986) The organization of the pudendal nerve in the male and female rat. J Comp Neurol 248:532-549.

Merry DE, Korsmeyer SJ (1997) Bcl-2 gene family in the nervous system. Annu Rev Neurosci 20:245-267.

Nicolopoulos-Stournaras S, Iles JF (1983) Motor neuron columns in the lumbar spinal cord of the rat. J Comp Neurol 217:75-85.

Nordeen EJ, Nordeen KW, Sengelaub DR, Arnold AP (1985) Androgens prevent normally occurring cell death in a sexually dimorphic spinal nucleus. Science 229:671-673.

Nowak JA, Malowitz J, Girgenrath M, Kostek CA, Kravetz AJ, Dominov JA, Miller JB (2004) Immortalization of mouse myogenic cells can occur without loss of $\mathrm{p} 16^{\mathrm{INK} 4 \mathrm{a}}, \mathrm{p} 19^{\mathrm{ARF}}$, or $\mathrm{p} 53$ and is accelerated by inactivation of Bax. BMC Cell Biol 5:1-14.

Oppenheim RW (1991) Cell death during development of the nervous system. Annu Rev Neurosci 14:453-501.

Park JJ, Howell M, Winseck A, Forger NG (1999) Effects of testosterone on the development of a sexually dimorphic neuromuscular system in ciliary neurotrophic factor receptor knockout mice. J Neurobiol 41:317-325.

Schroder HD (1980) Organization of the motoneurons innervating the pelvic muscles of the male rats. J Comp Neurol 192:567-587.

Siegford JM, Hadi Mansouri S, Ulibarri C (2003) Normal ontogeny of perineal muscles and testosterone levels in Mongolian gerbils; response to testosterone in developing females. Anat Rec 275A:997-1008.

Simerly RB, Zee MC, Pendleton JW, Lubahn DB, Korach KS (1997) Estrogen receptor-dependent sexual differentiation of dopaminergic neurons in the preoptic region of the mouse. Proc Natl Acad Sci USA 94:14077-14082.
Sun W, Oppenheim RW (2003) Response of motoneurons to neonatal sciatic nerve axotomy in Bax-knockout mice. Mol Cell Neurosci 24:875-876.

Sun W, Gould TW, Vinsant S, Prevette D, Oppenheim RW (2003) Neuromuscular development after the prevention of naturally occurring neuronal death by Bax deletion. J Neurosci 23:7298-7310.

Sun YF, Yu LY, Saarma M, Timmusk T, Arumae U (2001) Neuron-specific Bcl-2 homology 3 domain-only splice variant of Bak is anti-apoptotic in neurons, but pro-apoptotic in non-neuronal cells. J Biol Chem 276:16240-16247.

Tobin C, Joubert Y (1988) The levator ani of the female rat: a suitable model for studying the effects of testosterone on the development of mammalian muscles. Biol Struct Morphog 1:28-33.

Uo T, Kinoshita Y, Morrison RS (2004) Neurons exclusively express N-BAK, a BH3 domain-only BAK isoform that promotes neuronal apoptosis. J Biol Chem 280:9065-9073.

Venable JH (1966) Constant cell populations in normal, testosteronedeprived and testosterone-stimulated levator ani muscles. Am J Anat 119:263-270.

Wagner CK, Clemens LG (1989) Perinatal modification of a sexually dimorphic motor nucleus in the spinal cord of the B6D2F1 house mouse. Physiol Behav 45:831-835.

Wainman P, Shipounoff GC (1941) The effects of castration and testosterone propionate on the striated perineal musculature in the rat. Endocrinology 29:975-978.

Wei MC, Zong WX, Cheng EH, Lindsten T, Panoutsakopoulou V, Ross AJ, Roth KA, MacGregor GR, Thompson CB, Korsmeyer SJ (2001) Proapoptotic BAX and BAK: a requisite gateway to mitochondrial dysfunction. Science 292:727-730.

White FA, Keller-Peck CR, Knudson CM, Korsmeyer SJ, Snider WD (1998) Widespread elimination of naturally occurring neuronal death in Baxdeficient mice. J Neurosci 18:1428-1439.

Xu J, Gingras KM, Bengston CL, Di Marco A, Forger NG (2001) Blockade of endogenous neurotrophic factors prevents the androgenic rescue of rat spinal motoneurons. J Neurosci 21:4366-4372.

Zup SL, Carrier H, Waters EM, Tabor A, Bengston L, Rosen GJ, Simerly RB, Forger NG (2003) Overexpression of Bcl-2 reduces sex differences in neuron number in the brain and spinal cord. J Neurosci 23:2357-2362. 